\title{
Proteolysis is the most fundamental property of malignancy and its inhibition may be used therapeutically (Review)
}

\author{
MARZENA WYGANOWSKA-ŚWIĄTKOWSKA ${ }^{1}$, MATEUSZ TARNOWSKI ${ }^{2}$, DANIEL MURTAGH ${ }^{3}$, \\ EWA SKRZYPCZAK-JANKUN ${ }^{3}$ and JERZY JANKUN ${ }^{3}$ \\ ${ }^{1}$ Department of Dental Surgery and Periodontology, Poznań University of Medical Sciences, 60-820 Poznań; \\ ${ }^{2}$ Dagmed Medical Center, 60-681 Poznań, Poland; ${ }^{3}$ Urology Research Center, Department of Urology, \\ Health Science Campus, The University of Toledo, Toledo, OH 43614-2598, USA
}

Received March 17, 2018; Accepted September 6, 2018

DOI: $10.3892 /$ ijmm.2018.3983

\begin{abstract}
The mortality rates of cancer patients decreased by $\sim 1.5 \%$ per year between 2001 and 2015, although the decrease depends on patient sex, ethnic group and type of malignancy. Cancer remains a significant global health problem, requiring a search for novel treatments. The most common property of malignant tumors is their capacity to invade adjacent tissue and to metastasize, and this cancer aggressiveness is contingent on overexpression of proteolytic enzymes. The components of the plasminogen activation system (PAS) and the metalloproteinase family [mainly matrix metalloproteinases (MMPs)] are overexpressed in malignant tumors, driving the local invasion, metastasis and angiogenesis. This is the case for numerous types of cancer, such as breast, colon, prostate and oral carcinoma, among others. Present chemotherapeutics agents typically attack all dividing cells; however, for future therapeutic agents to be clinically successful, they need to be highly selective for a specific protein(s) and act on the cancerous tissues without adverse systemic effects. Inhibition of proteolysis in cancerous tissue has the ability to attenuate tumor invasion, angiogenesis and migration. For that purpose, inhibiting both PAS and MMPs may be another approach, since the two groups of enzymes are overexpressed in cancer. In the present review, the roles and new findings on PAS and MMP families in cancer formation, growth and possible treatments are discussed.
\end{abstract}

Correspondence to: Dr Marzena Wyganowska-Świątkowska, Department of Dental Surgery and Periodontology, Poznań University of Medical Sciences, Bukowska 70, 60-812 Poznań, Poland

E-mail: marzena.wyganowska@periona.pl

Professor Jerzy Jankun, Urology Research Center, Department of Urology, Health Science Campus, The University of Toledo, 3000 Arlington Avenue, Mail Stop 1091, Toledo, OH 43614-2598, USA

E-mail: jerzy.jankun@utoledo.edu

Key words: proteolysis, metalloproteinases, plasminogen activation system, cancer

\section{Contents}

1. Introduction

2. PAS family

3. Metalloproteinase family

4. Proteolysis in angiogenesis, invasion and metastasis

5. Inhibition of PAS in the treatment of cancer

6. Inhibition of MMPs in the treatment of cancer

7. Conclusion

\section{Introduction}

Research on cancer formation and treatment has finally started to reduce the mortality of cancer patients. In general, mortality rates decreased by $1.5 \%$ per year from 2001 through 2015 , although these rates may differ depending on patient sex, ethnic group and type of malignancy. Nevertheless, cancer remains a significant global health problem, requiring constant search for novel treatments (1). The most common property of the malignant tumors is their ability to invade adjacent tissue and to metastasize to distant sites $(2,3)$. This is due to increased expression or increased activity of numerous proteases associated with carcinogenesis (4-9). For example, cysteine proteases, such as cathepsin $\mathrm{B}$ and cathepsin $\mathrm{D}$, can take part in dissolving of connective tissue and basement membrane needed for invasion and metastasis. However, these become activated at the low $\mathrm{pH}$ of lysosomes, requiring transporting into regions of tumor cell invasion (10-13). Aspartate proteases and other protease enzymes also serve a role in cancer development and metastasis (14-16). Nevertheless, among all these proteolytic events, the plasminogen and metalloproteinase family members have an exceptional significance due to their ability to cleave virtually any element of the extracellular matrix and basement membrane (17-20).

The components of the plasminogen activation system (PAS) and matrix metalloproteinase (MMP) families have been found to be overexpressed in malignant tumors, revealing that tumors are hijacking these systems and using them in the local invasion, metastasis and angiogenesis (21-23). One of the hallmarks of this cancer aggressiveness is the overexpression of proteolytic enzymes (24-27). For instance, prostate cancer 
is the most common non-cutaneous malignancy in men with $>160,000$ new cases in the United States each year, and the median age of diagnosis is 68 years. This cancer grows slowly, and is initially confined to the gland, requiring marginal or no treatment at all. However, certain types of prostate cancer are aggressive, can spread quickly and exhibit high proteolytic activity (28-31). This is also a case for other types of cancer, such as breast, colon and oral carcinomas among others (32-36).

In the present review, new findings on the role of plasminogen activation system (PAS) and metalloproteinase families in cancer formation and growth were summarized, and the study explored whether targeting these two protein families can serve as a possible treatment strategy.

\section{PAS family}

Plasminogen/plasmin. Plasminogen is synthetized as a zymogen in the liver and released into the systemic circulation. In the circulation, plasminogen is resistant to activation by adopting a closed conformation. When bound to blood clots or to the cell surface, plasminogen changes to an open form that can be cleaved into active plasmin by a variety of enzymes. These enzymes are mainly plasminogen activators, namely tissue plasminogen activator (tPA) and urokinase plasminogen activator (UPA), while other enzymes include kallikrein and factor XII. Plasminogen is converted into plasmin by the cleavage of the peptide bond between Arg-561 and Val-562 $(37,38)$. Plasmin, a member of the serine protease family, was originally considered to only act to dissolve fibrin blood clots. However, in addition to fibrinolysis, plasmin cleaves proteins in numerous other systems. For instance, it activates collagenases, and cleaves fibronectin, thrombospondin, laminin and von Willebrand factor $(26,35,38)$. Two major forms of plasminogen are detected in humans, including type I and type II. Notably, type I plasminogen has two glycosylation moieties, namely N-linked to N289 and O-linked to T346, which is preferentially recruited to the cell surface. Type II plasminogen contains only O-linked sugar to T346, which appears to be more readily recruited to blood clots (39-41).

To prevent premature or unnecessary proteolysis, the activity of plasmin needs to be tightly controlled. Two proteins, $\alpha 2$-macroglobulin and $\alpha 2$-antiplasmin, inactivate plasmin, and the underlying mechanism involves the cleavage of $\alpha 2$-macroglobulin at the bait region by plasmin. This initiates a conformational change resulting in the a2-macroglobulin-plasmin complex, where the active site of plasmin is sterically shielded, decreasing the access of plasmin to its substrates (42). In addition, a major conformational change exposes a conserved $\mathrm{COOH}$-terminal receptor binding domain that allows the $\alpha 2$-macroglobulin protease complex to bind to clearance receptors and consequently be removed from the circulation (43). Furthermore, $\alpha 2$-antiplasmin forms an irreversible complex with plasmin by attaching to Arg-376 in the reactive center loop, resulting in the complete loss of plasmin activity (42).

A rare disorder in humans known as plasminogen deficiency type I may lead to thrombosis, as blood clots are not effectively degraded. Plasminogen deficiency in humans is caused by numerous mutations and polymorphisms in plasminogen gene and is often manifested by ligneous conjunctivitis (44). Ligneous conjunctivitis is characterized by fibrin-rich pseudomembranous lesions that develop mainly on the underside of the eyelid, which can be sight-threatening (45). It may also influence the periodontal tissue, upper and lower respiratory tract, kidneys, middle ear and female genitalia, and affects wound healing (46-50).

Plasminogen activators. There are two main plasminogen activators, uPA and tPA $(35,51,52)$, which are weak but specific proteolytic enzymes that activate plasminogen to plasmin by proteolytic cleavage. tPA mainly mediates intravascular thrombolysis, while uPA is involved in pericellular proteolysis during cell migration, wound healing and tissue remodeling under a variety of physiological and pathological conditions (35).

$t P A$. The encoded preprotein of tPA is proteolytically cleaved by plasmin or trypsin to produce heavy and light chains. These chains are linked by disulfide bridges to form an active heterodimeric enzyme that is able to activate plasminogen (53). Increased tPA activity triggers hyperfibrinolysis, which causes excessive bleeding and an increase of the vascular permeability (54-57), while decreased activity leads to hypofibrinolysis, which can result in thrombosis or embolism (58-60).

$u P A$. Similar to tPA, uPA is synthetized as a preprotein and is activated by cleavage at a Lys-Ile bond by plasmin to form a two-chain enzyme connected by a disulfide bond. In its active form, uPA contains the amino terminal A-chain that is catalytically active, and the carboxy-terminal B-chain. This two-chain derivative form is referred to as high molecular weight uPA (HMW-uPA). HMW-uPA can be cleaved at the A-chain into a short chain A (A1), forming low molecular weight uPA (LMW-uPA) and an amino-terminal fragment. LMW-uPA is able to activate plasminogen, however, it does not bind to the uPA receptor ( $\mathrm{UPAR})(61,62)$. A C/T single-nucleotide polymorphism (SNP) in codon 141 of urokinase (known as P141L) may be associated with late onset Alzheimer's disease, decreased affinity for fibrin-binding (63) and reduced risk of Helicobacter pylori infection (64).

Urokinase receptor. UPAR, also known as cluster of differentiation 87 (CD87), was originally identified as a saturable binding site for uPA and contains three domain glycoprotein bound to the cell surface with a glycosylphosphatidylinositol (GPI) anchor. All domains of UPAR are needed for high affinity binding of the urokinase $(21,27,35)$. Urokinase receptor anchors UPA and therefore confines plasminogen activation in the vicinity of the cell membrane. However, when uPA is bound to its receptor, it may be cleaved in the proximity of the GPI anchor, and the UPAR is released as a soluble receptor (65-67). Urokinase receptor has also been suggested to be involved in non-proteolytic processes, such as cancer, cell migration, cell cycle regulation or cell adhesion (35,65-67). A previous study reported that $\mathrm{rs} 344781$ (516 T/C) UPAR polymorphism was implicated in systemic sclerosis vasculopathy, impaired angiogenesis (68) and the severity of lung cancer (69). 


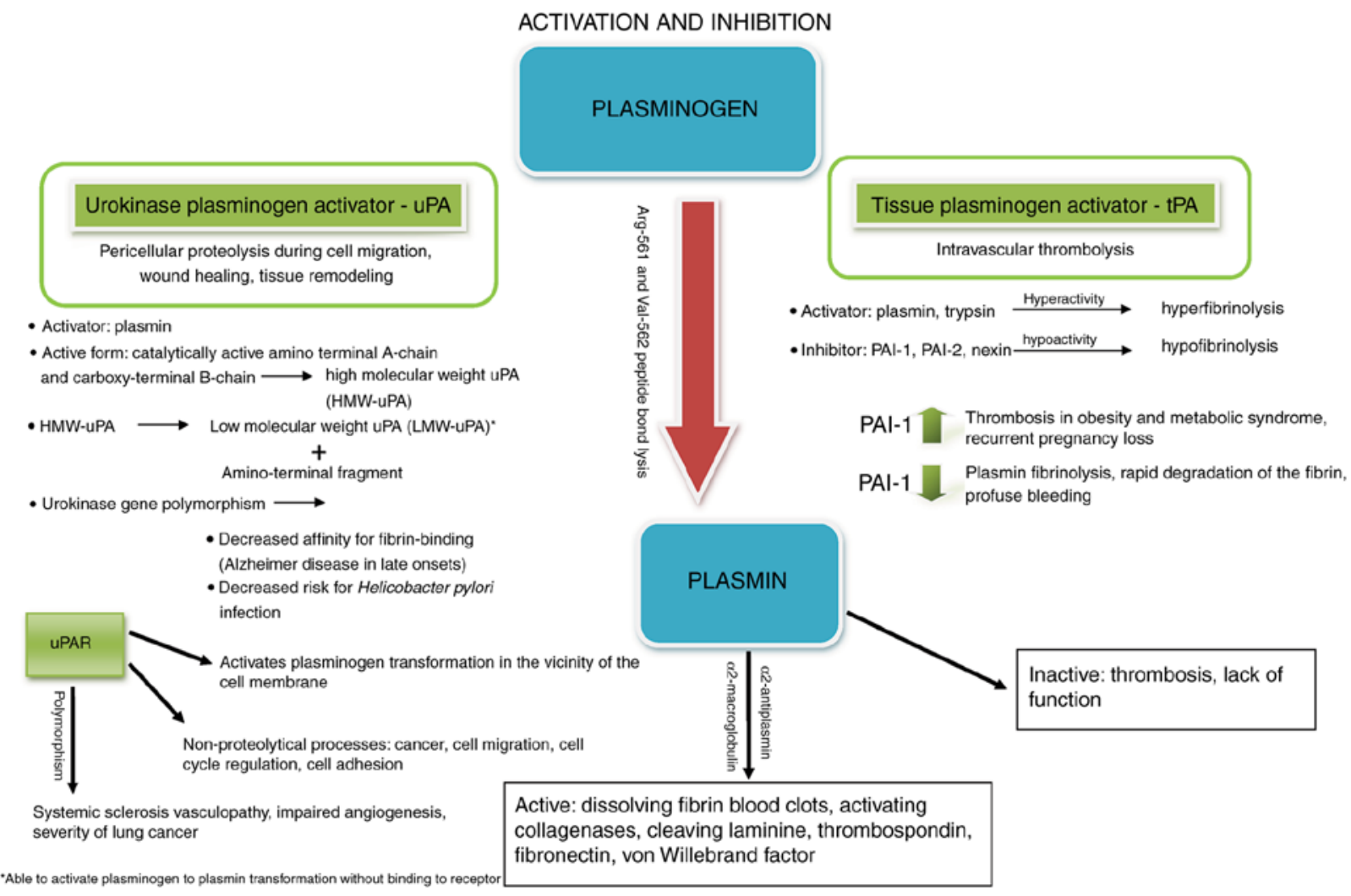

Figure 1. Diverse functions of plasminogen activation system.

Inhibitors of plasminogen activators. Plasminogen activator inhibitor-1 (PAI-1), also known as endothelial PAI or serine protease inhibitor E1, is a fast-acting, high-affinity, principal inhibitor of tPA and UPA. The other PAI, namely PAI-2, is only produced in physiologically significant amounts during pregnancy and secreted by the placenta. Protease nexin can also inhibit tPA and uPA, however, PAI-1 remains a major inhibitor of plasmin-driven proteolysis (35,70-72). PAI-1 is overexpressed in various diseases, such as obesity and metabolic syndrome, and has been linked to risk of thrombosis in patients with these conditions $(36,73,74)$. Also, it has been reported that a high activity of PAI-1 is associated with recurrent pregnancy loss $(75,76)$. By contrast, a low level of PAI-1 leads to excessive plasmin fibrinolysis that is unopposed by PAI-1 and rapid degradation of the fibrin, which may manifest in profuse bleeding. Indeed, it was reported that a life-long bleeding tendency was caused by undetectable PAI-1 activity and antigen levels in a 76-year-old man, while severe menorrhagia has been reported in patients with a low PAI-1 antigen level (77-79). Notably, in the case of low activity of PAI-1, women have achieved pregnancy without difficulty, but experienced antenatal bleeding and preterm labor (80).

The promoter polymorphisms ( $844 \mathrm{~A} / \mathrm{G}$ and $6754 \mathrm{G} / 5 \mathrm{G})$ in the PAI-1 gene yield higher plasma PAI-1 levels (81). Another SNP with substitution of A15 to T15 and possibly V17 to Ile in the signal peptide leads to lower PAI-1 activity compared with a control $(78,82,83)$. In addition, a previous study reported that a young Amish girl and certain members of her extended immediate family had no PAI-1 antigen and PAI-1 activity. In addition, a previous study reported that a young Caucasian girl from an Amish congregation and certain members of her extended family had no PAI-1 antigen and PAI-1 activity, leading to excessive bleeding. They were found to be homozygous for a dinucleotide insertion within exon 4 of PAI- 1 gene, producing a truncated, non-functional protein $(78,79)$. The diverse function of PAS, as discussed in the present study, is outlined in Fig. 1.

\section{Metalloproteinase family}

Matrix metalloproteinases (MMPs). MMPs also known as matrixins, are metal-dependent (Ca and $\mathrm{Zn}$ ) endopeptidases that belong to a larger family known as the metzincin superfamily (84-87). These enzymes degrade all types of extracellular matrix proteins and are differentiated from other endopeptidases by their dependence on metal ions as cofactors $(88,89)$. MMPs are synthesized as inactive zymogens with a domain that must be removed to activate enzymes. This domain is part of the cysteine switch, containing a cysteine residue that prevents metals binding and keeps the enzyme in an inactive form (90-93). Matrix metalloproteinases are also involved in cell proliferation, migration, differentiation, angiogenesis and apoptosis $(92,94)$.

MMP-2 and MMP-9, two members of the 25-protein family of MMPs, are considered to be critical in local invasion and metastasis of cancer in humans $(94,95)$. One of the most important functions of these enzymes in cancer progression is their ability of extracellular matrix degradation, which enables cancer cells to migrate out of the primary tumor site and to form metastases. Both MMP-2 and MMP-9 are capable of degrading type IV collagen, the most abundant component 


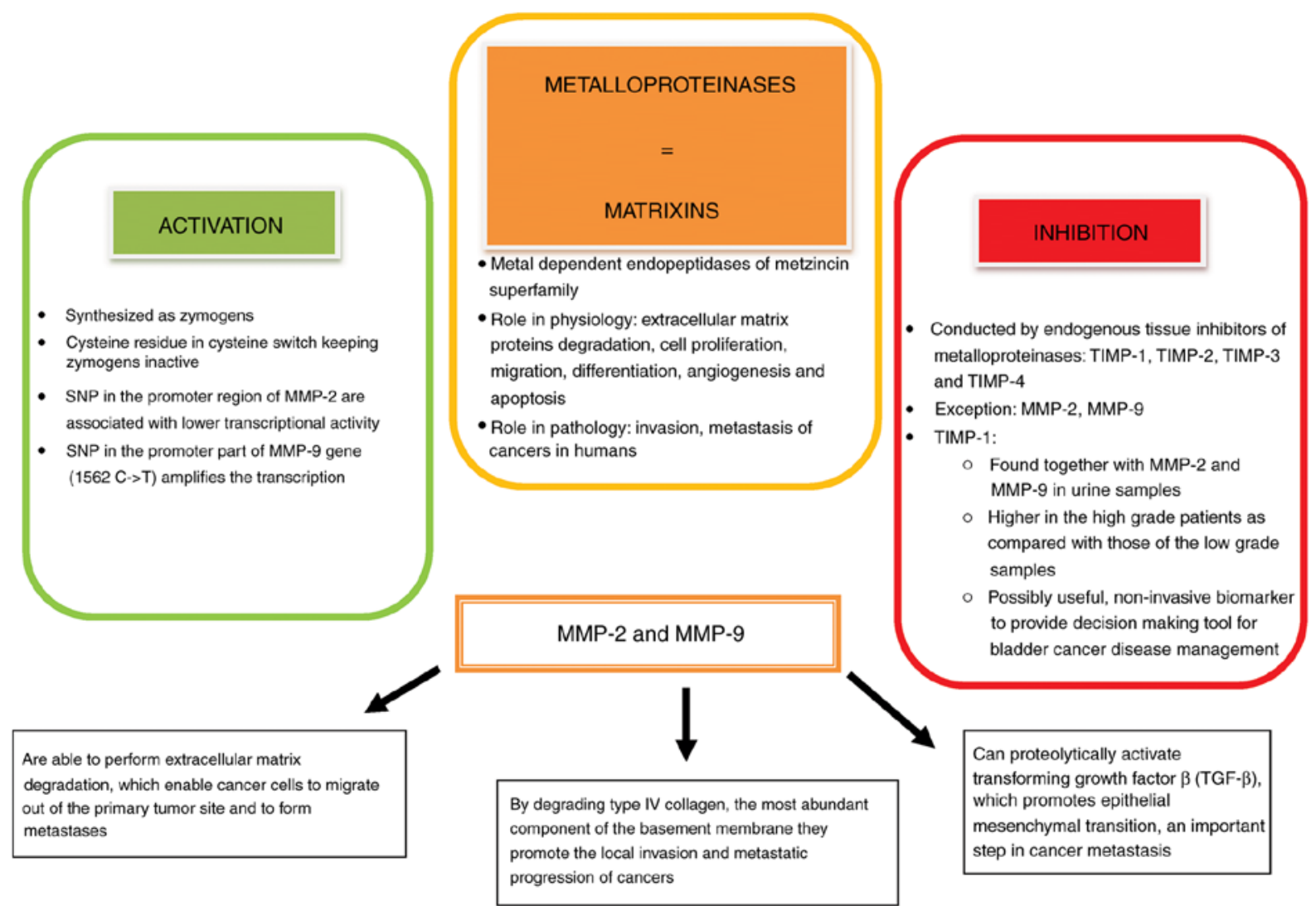

Figure 2. Diverse functions of metalloproteinases. SNP, single-nucleotide polymorphism; MMP, matrix metalloproteinase; TIMP, tissue inhibitor of metalloproteinase.

of the basement membrane, which is an essential step for the local invasion and metastatic progression of cancer $(95,96)$. In addition, MMP-2 and certain other MMPs can proteolytically activate transforming growth factor $\beta$, which promotes epithelial mesenchymal transition, an important step in cancer metastasis $(96,97)$. Diverse functions of metalloproteinases are outlined in Fig. 2.

SNPs in the promoter region of MMP-2 (1306C->T and $735 \mathrm{C}->\mathrm{T})$ are associated with lower transcriptional activity, and the SNP in the promoter part of MMP-9 gene (1562C->T) amplifies the transcription of this metalloproteinase gene. Others SNPs in the coding region of the MMP-9 gene include $836 \mathrm{~A}>\mathrm{G}, 1721 \mathrm{G}>\mathrm{C}$ and $2003 \mathrm{G}>\mathrm{A}$, which produce a missense amino acid sequence, reducing the substrate and inhibitor binding ability of MMP-9 $(98,99)$.

Tissue inhibitor of metalloproteinase (TIMP). MMPs are inhibited by four different specific endogenous tissue inhibitors: TIMP-1, TIMP-2, TIMP-3 and TIMP-4. All MMPs are inhibited by TIMPs when in their active form, with the exception of MMP-2 and MMP-9, which can form complexes with TIMPs in the latent form $(99,100)$. Ricci et al (101) investigated MMP-2 and MMP-9, as well as the inhibitors TIMP-1 and TIMP-2 in the urine and sera of bladder cancer patients. The data revealed that urinary TIMP-1 was significantly higher in high-grade patients, as compared with the levels in the low-grade samples (101). The results also revealed a significantly differing distribution of TIMP-1 expression between Ta and T1 stage specimens, and the authors concluded that urinary TIMP-1 can be a useful, non-invasive biomarker that may serve as a decision making tool for bladder cancer disease management (101). Three SNPs were reported in TIMP-1, including 261 C->T, 328+16 C->T and $372 \mathrm{~T}->\mathrm{C}$, (102), while six SNPs were reported in TIMP-2, including rs2277698 T->C, rs2009196 C->G, rs7342880 A->C, rs11654470 C->T, rs2003241 C->T, rs4789936 T->C (103).

\section{Proteolysis in angiogenesis, invasion and metastasis}

The hallmark of metastatic disease is an altered equilibrium between the synthesis and degradation of the extracellular matrix proteins during pathological angiogenesis, invasion and metastasis $(35,102)$.

Angiogenesis. Angiogenesis is the physiological or pathological development of revascularization from existing vessels. It is a normal process during growth and development, and in wound healing; however, angiogenesis is also an essential step in malignant tumor growth $(26,27,34,35)$. Sprouting angiogenesis occurs as angiogenic growth factors activate receptors on endothelial cells, followed by the release of proteases (PAS and MMP) that degrade the basement membrane, permitting cells to escape in tandems to or from the vessel walls $(35,110)$. The endothelial cells then proliferate into the surrounding matrix and form solid sprouts, connecting neighboring vessels. These processes are basically the same in both normal and aberrant angiogenesis $(26,35,104)$. 
A
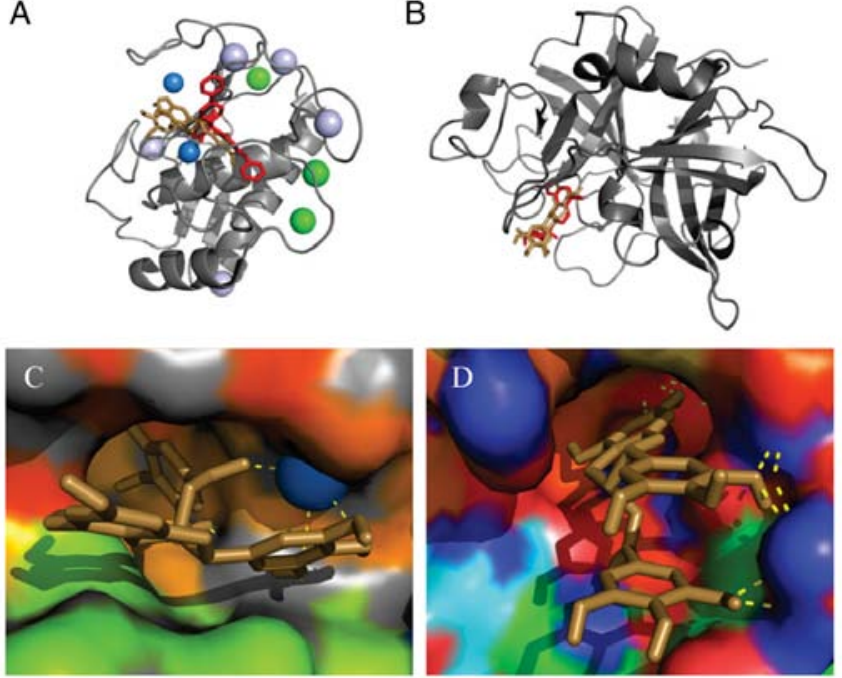

Figure 3. Ribbon model of (A) MMP-9 and inhibitors, and (B) uPA and inhibitors. The inhibitors of MMP-9 and uPA are shown as sticks models in red, while ions in MMP-9 are shown as spheres (blue, $\mathrm{Zn}^{2+}$; light blue, $\mathrm{Ca}^{2+}$; green, $\mathrm{Cl}^{-}$). Surface of active site of (C) MMP-9 and (D) uPA Epigallocatechin gallate is shown as a stick model in light brown. Polar contacts are shown as the yellow dotted lines [reprinted with permission from the study of Jankun et al (113)]. MMP-9, matrix metalloproteinase 9; uPA, urokinase plasminogen activator.

Invasion and metastasis. Lah et al (105) introduced definition of 'degradome' that includes proteases associated with degradation of adjacent tissue during cancer invasion and metastasis. The study stressed that invasion and metastasis were initially considered to occur as late events in cancer development. However, other studies have indicated that these processes are also highly depended on proteases activity that takes place during early stages of cancer development $(105,106)$.

\section{Inhibition of PAS in the treatment of cancer}

It has previously been reported that receptor-bound uPA on the cancer cell surface is overexpressed in final step of malignant cell transformation that is responsible for invasion and metastasis (107). In addition, uPA has been implicated in the basement membrane and interstitial protein degradation during carcinogenesis, and is responsible for the disease progression (108-110). Therefore, inhibition of uPA may be beneficial in the treatment of cancer by limiting or preventing tumor growth and metastasis $(26,111,112)$. Historically, one of the first uPA specific inhibitors identified was amiloride, which limits tumor growth and angiogenesis, as proven by in vitro and in vivo models $(26,108,110,111,113)$. Amiloride has been approved by the Food and Drug Administration as a diuretic agent, however, it is not currently used in anticancer therapy.

The availability of the high resolution structure of uPA and sophisticated molecular modeling methods have aided the development of inhibitors binding to uPA. The specificity pocket of uPA is a part of this enzyme, which is responsible for the recognition of uPA substrates, therefore binding to the specificity pocket promises high specificity of inhibitors $(35,67,105)$. Several 8-substituted 2-naphthamidine-based inhibitors with specific binding to uPA with high potency and selectivity were developed by Wendt et al (114). Among the

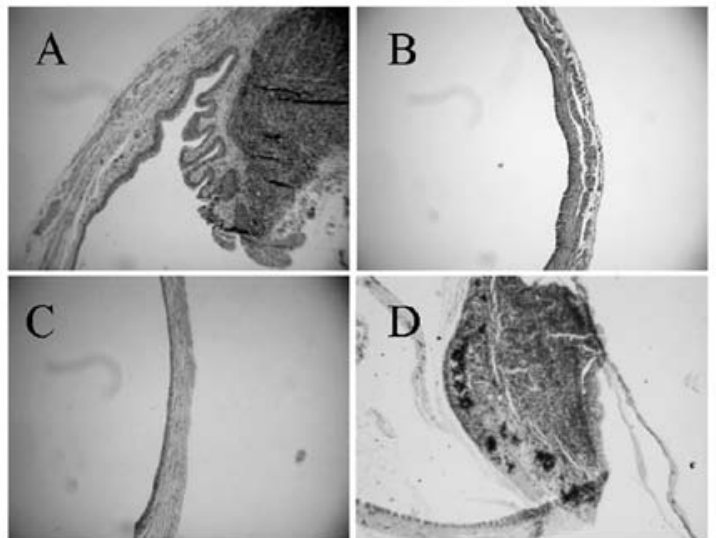

Figure 4. Typical microscopic appearance (reduced from x40 magnification) of: (A) Control bladder with tumors; (B) tumor-free bladder following treatment with $400 \mu \mathrm{M}$ epigallocatechin gallate; $(\mathrm{C})$ tumor-free bladder treated with $400 \mu \mathrm{M}$ MMC; (D) bladder with tumors treated with $400 \mu \mathrm{M}$ MMC at 3 days after surgery [reprinted with permission from the study of Jankun et al (113)]. MMC, mitomycin C.

multiple novel inhibitors developed by the Bruncko et al (115) and Katz et al (116) groups, only a limited number of inhibitors were translated into clinical practice. One of these is WX-UK1, also known as ethyl 4-[3-(3-carbamimidoylphenyl)2-[[2,4,6-tri(propan-2-yl)phenyl]sulfonylamino]propanoyl] piperazine-1-carboxylate or Mesupron ${ }^{\circledR}$, which is one of the most potent uPA inhibitors $(0.41 \mu \mathrm{M})$, and is currently in Phase I clinical trial for pancreatic and breast cancer, with the possibility of application in ovarian and colon cancer as well (117-120).

Another possibility for inhibiting uPA is through the use of antibodies. For instance, a number of studies by Ossowski $(121,122)$ have reported that the ability to invade the chick chorioallantoic membrane and metastasize from it to the embryo was evidently reduced for human carcinoma cells expressing a high amount of uPA during treatment with the antibody against the active site of uPA, in comparison to non-treated cells.

PAI-1 is also an attractive molecule for anticancer therapy, since it is a fast-acting, specific and high-affinity inhibitor of uPA $(35,123)$. However, only active PAI-1 can be used to control angiogenesis, invasion and metastasis of malignant tumors. The half-life of wild-type PAI-1 is very short $\left(t_{1 / 2}=1-2 \mathrm{~h}\right)$, after which it converts into its inactive latent form. This transformation is associated with the insertion of part of the reactive loop (P4-P10') into the central $\beta$-sheet of the PAI-1 molecule, where P1-P1' amino acids are not accessible for reaction with tPA or uPA $(35,124)$. For that reason, wild-type PAI-1 cannot be used in anti-cancer therapy. Numerous engineered PAI-1 molecules with two or more mutations were developed, which exhibited a half-life extended from $2 \mathrm{~h}$ to $>700 \mathrm{~h}$, opening a possibility for their application in clinical settings (124-126). For instance, VLHL PAI-1 $\left(\mathrm{t}_{1 / 2}=>700 \mathrm{~h}\right)$ has been demonstrated to inhibit angiogenesis and reduce tumor size in different ex vivo and in vivo models $(26,71,110)$.

Notably, PAI-1-deficient mice exhibited lower tumor proliferation and higher apoptosis of implanted tumors when compared with their wild-type counterparts. Additionally, an elevated PAI-1 level is a predictive factor of poor prog- 
nosis in invasive breast cancer in humans $(34,127,128)$. When PAI-1 was administrated in low concentrations, it was able to increase the metastatic potential and angiogenesis (34,127-129). These observations contradict our previous statements suggesting that PAI-1 is a potent inhibitor of angiogenesis and tumor growth $(26,125,128,130)$. This paradox can be explained by the interaction of PAI-1 with vitronectin. This protein is a multifunctional glycoprotein present in the plasma, platelets and the extracellular matrix. PAI-1 binds to vitronectin and then binds with uPA/uPAR, forming a four protein complex (namely uPAR/uPA/PAI-1/vitronectin), which can be further combined with LDL receptor-related protein. This interaction weakens the PAI-1/vitronectin binding and triggers PAI-1/uPA/uPAR internalization. PAI-1 and $\mathrm{UPA}$ are degraded, whereas uPAR is recycled to the cell surface. Subsequently, uPAR can bind to UPA again and form a new PAI-1/uPA/uPAR/vitronectin complex. This process clears PAI-1 in the immediate vicinity of the cell, forcing it to migrate toward increased concentration of PAI-1 $(131,132)$. Thus, PAI-1 can have a dual function as a pro-carcinogenic and anti-cancer agent, depending on its concentration. PAI-1 in physiological concentration acts by utilizing the vitronectin pathway. However, as it has been demonstrated in our previous studies and by other groups, when PAI-1 is present in much higher supraphysiologic concentrations, it suppresses the vitronectin pathway and acts as a potent inhibitor of angiogenesis by utilizing primarily its inhibitory properties to block proteinase activity (133-136).

uPAR (or CD87) is a multidomain glycoprotein attached to the cell membrane with a glycosylphosphatidylinositol (GPI) anchor. When binding to UPA, it creates high proteolytic activity in the proximity of the cell surface (137-139). Therefore, another approach to prevent invasion or metastasis is to block the binding of UPA to its receptor on the cancer cell surface. Similarly, limiting the binding of uPA to vascular cells would reduce cancer-associated angiogenesis. An octapeptide A6 (amino acids 136-143; nonreceptor-binding domain) of uPA inhibits the interaction of uPA with its receptor uPAR, and was reported to inhibit endothelial cell motility and tumor cell invasion $(117,140,141)$. Furthermore, the use of this polypeptide has been reported in Phase I and II clinical studies of gynecological cancer (142). Mani et al (143) synthesized a methyl 3-aminobenzoate derivative that binds to uPAR with high affinity and demonstrated that this UPAR inhibitor lowers the invasion ability of breast MDA-MB-231 cells. In addition, female NSG mice inoculated with highly malignant TMD-MDA-MB-231 cells presented impaired metastasis to the lungs when treated with this UPAR inhibitor (143). In a subsequent study by Wang et al (144), the affinity of a large number of derivatives was measured using structure-based virtual screening. The synthesis of additional and cellular studies in cell lines (A549, H460 and H1299) revealed that these compounds blocked invasion, migration and adhesion, while the effects of these compounds on invasion were consistent with their inhibition of uPAR (144). Treatment of metastatic liver cells with 1 or $4 \mathrm{~g} / \mathrm{ml}$ lectin from Bandeiraea simplicifolia seeds significantly inhibited the cell migration and invasion, and downregulated MMP2, MMP9 and UPA production (145). Furthermore, the AKT/GSK-3b/ $\beta$-catenin pathway, which is upstream of MMP2, MMP9 and UPA, was found to be involved in the inhibition of cell migration and invasion by lectin (145). In a similar manner, quercetin functions on the uPA/uPAR system (146).

A total of 14 clinical studies can be found in the clinicaltrials.gov registry on PAS and cancer. However, results have been posted for only one of these studies, and this study was abandoned due to limited activity of the agent (https://ccr. cancer.gov/news/clinical-trials). The diverse function of PAS is outlined in Fig. 1.

\section{Inhibition of MMPs in the treatment of cancer}

Inhibitors targeting MMP activity were initially intended to target the catalytic domain of these enzymes. The most clear approach was to synthetize polypeptides derived from the sequences of the amino acids of the MMP substrates, preventing hydrolysis of the scissile bond of proteins (147). Batimastat (INN/USAN, codenamed BB-94), a broad-spectrum, competitive, injectable drug was the first MMP inhibitor (MMPI) to go into clinical trials, acting as an angiogenesis inhibitor. While this agent reached Phase III trials, it was never marketed due to side effects (injection into the peritoneum caused peritonitis), poor solubility and very low oral bioavailability (147-149). Marimastat, another MMPI drug, exhibited some effects in delaying disease progression; however, it also had a dose-limiting toxicity. Patients experienced significant musculoskeletal pain and inflammation, and the clinical study was discontinued $(147,150)$. The small molecular inhibitors of MMPs failed for a variety of reasons, despite preclinical data demonstrating their great potential for therapeutic use, leading to cancelled phase I trials on Prinomastat, and cancelled phase III trials on Batimastat, Marimastat, Tanomastat and CGS 27023A, which is a doxycycline tetracycline derivative (147).

Using hybridoma methods against the MMP-9 catalytic domain, Martens et al (151) generated the murine monoclonal antibody REGA-3G12. This antibody recognizes the W116 to K214 of the human MMP-9 catalytic domain, but not the $\mathrm{Zn}^{2+}$ binding site (151). The REGA-3G12 antibody inhibits MMP-9, but not MMP-2 (151,152). However, while MMPs have been recognized as a marker of poor prognosis and are one of the major classes of proteolytic enzymes involved in tumor invasion and metastasis, inhibitory monoclonal antibodies against MMPs have yet to find broad clinical applications.

Clinical studies on MMPs in cancer. In total, 62 clinical studies can be found in the clinicaltrials.gov registry on MMP and cancer. Several of these have been completed; however, none of the studies have posted results and numerous were abandoned (https://ccr.cancer.gov/news/clinical-trials) $(135,147,148,150)$.

\section{Conclusion}

The mainstream of the presently used chemotherapeutic agents attack all dividing cells, leading to the adverse effects that are typically associated with cancer treatment, such as hair loss or loss of appetite. For future therapeutics to be clinically successful, they need to be highly selective for a specific protein or proteins, and able to act on the cancerous tissues without causing adverse systemic effects. Despite unsuccessful early clinical studies on the inhibition of proteolysis in cancer (particularly MMPs), this 
approach still has great potential for therapeutic use. Inhibition of proteolysis in cancerous tissue has the ability to attenuate tumor invasion, angiogenesis and migration, which are the most fundamental properties of malignant tumors, thus deserving future development $(147,153)$. This includes application of inhibitors at the time and stage of malignancy for which regulation of pathological proteolysis will be most beneficial. For instance, inhibiting cancer proteolytic enzymes during or after surgery can prevent cancer cell implantation and consequently cancer reemission (113). Inhibiting both uPA and MMPs is another beneficial approach, since tumors overexpress these groups of enzymes; therefore, employing this simple concept can be equally beneficial as cancer cell killing (Fig. 3). Epigallocatechin gallate, an inhibitor of uPA and MMPs, has previously been used, and this agent had a weak lethality, but prevented cancer cell implantation into the bladder wall following surgery and was slightly better in reducing cancer growth when compared with mitomycin C (Fig. 4) (113). Inhibition of PAS and MMPs simultaneously by a cocktail of inhibitors or a single inhibitor that is active against both proteolytic enzymes in all other types of cancer remains unexplored, but is a promising therapeutic approach deserving future development.

\section{Acknowledgements}

Not applicable.

\section{Funding}

No funding was received.

\section{Availability of data and materials}

Not applicable.

\section{Authors' contributions}

MWS, ESJ and JJ conceived the review and analyzed the relevant literature. MWS and JJ wrote the first draft of the manuscript. MT and DM collected literature and wrote the manuscript. ESJ collected literature and critically revised the manuscript. JJ and MT created the figures. All authors read and approved the final manuscript.

\section{Ethics approval and consent to participate}

Not applicable.

\section{Patient consent for publication}

Not applicable.

\section{Competing interests}

The authors declare that they have no competing interests.

\section{References}

1. Rosso T, Bertuccio P, La Vecchia C, Negri E and Malvezzi M Cancer mortality trend analysis in Italy, 1980-2010, and predictions for 2015. Tumori 101: 664-675, 2015.
2. Jankun J, Merrick HW and Goldblatt PJ: Expression and localization of elements of the plasminogen activation system in benign breast disease and breast cancers. J Cell Biochem 53: 135-144, 1993.

3. Kiziridou AD, Toliou T, Stefanou D and Agnantis N: u-PA expression in benign, borderline and malignant ovarian tumors. Anticancer Res 22: 985-990, 2002.

4. Safavi $\mathrm{F}$ and Rostami A: Role of serine proteases in inflammation: Bowman-Birk protease inhibitor (BBI) as a potential therapy for autoimmune diseases. Exp Mol Pathol 93: 428-433, 2012.

5. Van Hove I, Lemmens K, Van de Velde S, Verslegers M and Moons L: Matrix metalloproteinase- 3 in the central nervous system: A look on the bright side. J Neurochem 123: 203-216, 2012

6. van der Vorst EP, Keijbeck AA, de Winther MP and Donners MM: A disintegrin and metalloproteases: Molecular scissors in angiogenesis, inflammation and atherosclerosis. Atherosclerosis 224: 302-308, 2012.

7. Zheng D, Chen H, Bartee MY, Williams J, Davids JA, Huang E, Moreb $\mathrm{J}$ and Lucas A: Virus-derived anti-inflammatory proteins: Potential therapeutics for cancer. Trends Mol Med 18: 304-310, 2012.

8. Avgeris M, Mavridis K and Scorilas A: Kallikrein-related peptidases in prostate, breast, and ovarian cancers: from pathobiology to clinical relevance. Biol Chem 393: 301-317, 2012.

9. Frank A, David V, Aurelie TR, Florent G, William H and Philippe B: Regulation of MMPs during melanoma progression: From genetic to epigenetic. Anticancer Agents Med Chem 12: 773-782, 2012.

10. Pulz LH and Strefezzi RF: Proteases as prognostic markers in human and canine cancers. Vet Comp Oncol 15: 669-683, 2017.

11. Liu WL, Liu D, Cheng K, Liu YJ, Xing S, Chi PD, Liu XH, Xue N, Lai YZ, Guo L and Zhang G: Evaluating the diagnostic and prognostic value of circulating cathepsin $\mathrm{S}$ in gastric cancer. Oncotarget 7: 28124-28138, 2016.

12. Pišlar A, Perišić Nanut M and Kos J: Lysosomal cysteine peptidases-Molecules signaling tumor cell death and survival. Semin Cancer Biol 35: 168-179, 2015.

13. Wallin H, Abrahamson M and Ekstrom U: Cystatin C properties crucial for uptake and inhibition of intracellular target enzymes. J Biol Chem 288: 17019-17029, 2013.

14. Eatemadi A, Aiyelabegan HT, Negahdari B, Mazlomi MA, Daraee H, Daraee N, Eatemadi R and Sadroddiny E: Role of protease and protease inhibitors in cancer pathogenesis and treatment. Biomed Pharmacother 86: 221-231, 2017.

15. Hahlbrock A, Goesswein D, Kunzel J, Wünsch D and Stauber RH: Threonine Aspartase1: An unexplored protease with relevance for oral oncology? Oral Oncol 54: e10-e12, 2016.

16. Werner AB, Tait SW, de Vries E, Eldering E and Borst J: Requirement for aspartate-cleaved bid in apoptosis signaling by DNA-damaging anti-cancer regimens. J Biol Chem 279: 28771-28780, 2004.

17. Verollet C, Charrière GM, Labrousse A, Cougoule C, Le Cabec V and Maridonneau-Parini I: Extracellular proteolysis in macrophage migration: Losing grip for a breakthrough. Eur J Immunol 41: 2805-2813, 2011.

18. Roycik MD, Fang X and Sang QX: A fresh prospect of extracellular matrix hydrolytic enzymes and their substrates. Curr Pharm Des 15: 1295-1308, 2009.

19. Christiaens V and Lijnen HR: Role of the fibrinolytic and matrix metalloproteinase systems in development of adipose tissue. Arch Physiol Biochem 112: 254-259, 2006.

20. Riddick AC, Shukla CJ, Pennington CJ, Bass R, Nuttall RK, Hogan A, Sethia KK, Ellis V, Collins AT, Maitland NJ, et al: Identification of degradome components associated with prostate cancer progression by expression analysis of human prostatic tissues. Br J Cancer 92: 2171-2180, 2005.

21. Alfano D, Franco P, Vocca I, Gambi N, Pisa V, Mancini A, Caputi M, Carriero MV, Iaccarino I and Stoppelli MP: The urokinase plasminogen activator and its receptor: Role in cell growth and apoptosis. Thromb Haemost 93: 205-211, 2005.

22. Carriero MV and Stoppelli MP: The urokinase-type plasminogen activator and the generation of inhibitors of urokinase activity and signaling. Curr Pharm Des 17: 1944-1961, 2011.

23. Liu Y, Wang Y, Teng Z, Chen J, Li Y, Chen Z, Li Z and Zhang Z: Matrix metalloproteinase 9 expression and survival of patients with osteosarcoma: A meta-analysis. Eur J Cancer Care (Engl) 26: e12364, 2017.

24. Hadler-Olsen E, Winberg JO and Uhlin-Hansen L: Matrix metalloproteinases in cancer: Their value as diagnostic and prognostic markers and therapeutic targets. Tumour Biol 34: 2041-2051, 2013. 
25. Woodward JK, Holen I, Coleman RE and Buttle DJ: The roles of proteolytic enzymes in the development of tumour-induced bone disease in breast and prostate cancer. Bone 41: 912-927, 2007.

26. Swiercz R, Keck RW, Skrzypczak-Jankun E, Selman SH and Jankun J: Recombinant PAI-1 inhibits angiogenesis and reduces size of LNCaP prostate cancer xenografts in SCID mice. Oncol Rep 8: 463-470, 2001.

27. Rabbani SA and Xing RH: Role of urokinase (uPA) and its receptor (UPAR) in invasion and metastasis of hormone-dependent malignancies. Int J Oncol 12: 911-920, 1998.

28. Gupta S, Gupta A, Saini AK, Majumder K, Sinha K and Chahal A: Prostate cancer: How young is too young? Curr Urol 9: 212-215, 2017.

29. Johnston TJ, Shaw GL, Lamb AD, Parashar D, Greenberg D, Xiong T, Edwards AL, Gnanapragasam V, Holding $\mathrm{P}$ Herbert $\mathrm{P}$, et al: Mortality among men with advanced prostate cancer excluded from the protect trial. Eur Urol 71: 381-388, 2017

30. Litwin MS and Tan HJ: The diagnosis and treatment of prostate cancer: A review. JAMA 317: 2532-2542, 2017.

31. Macedo F, Ladeira K, Pinho F, Saraiva N, Bonito N, Pinto L and Goncalves F: Bone metastases: An overview. Oncol Rev 11: 321, 2017.

32. Hildenbrand R, Allgayer H, Marx A and Stroebel P: Modulators of the urokinase-type plasminogen activation system for cancer Exp Opin Investig Drugs 19: 641-652, 2010.

33. Honkavuori M, Talvensaari-Mattila A, Puistola U, Turpeenniemi-Hujanen T and Santala M: High serum TIMP-1 is associated with adverse prognosis in endometrial carcinoma. Anticancer Res 28: 2715-2719, 2008.

34. Isogai C, Laug WE, Shimada H, Declerck PJ, Stins MF, Durden DL, Erdreich-Epstein A and DeClerck YA: Plasminogen activator inhibitor-1 promotes angiogenesis by stimulating endothelial cell migration toward fibronectin. Cancer Res 61: $5587-5594,2001$

35. Jankun J and Skrzypczak-Jankun E: Yin and yang of the plasminogen activator inhibitor. Pol Arch Med Wewn 119: 410-417, 2009.

36. Kodaman N, Aldrich MC, Sobota R, Asselbergs FW, Brown NJ, Moore JH and Williams SM: Plasminogen activator inhibitor-1 and diagnosis of the metabolic syndrome in a west african population. J Am Heart Assoc 5: e003867, 2016.

37. Forsgren $M$, Råden $B$, Israelsson $M$, Larsson $K$ and Hedén LO Molecular cloning and characterization of a full-length cDNA clone for human plasminogen. FEBS Lett 213: 254-260, 1987.

38. Miyata T, Iwanaga S, Sakata Y and Aoki N: Plasminogen Tochigi: Inactive plasmin resulting from replacement of alanine-600 by threonine in the active site. Proc Natl Acad Sci USA 79: 6132-6136, 1982

39. Borisov OV, Field M, Ling VT and Harris RJ: Characterization of oligosaccharides in recombinant tissue plasminogen activator produced in Chinese hamster ovary cells: Two decades of analytical technology development. Anal Chem 81: 9744-9754, 2009

40. Hatton MW, Day S, Ross B, Southward SM, DeReske M and Richardson M: Plasminogen II accumulates five times faster than plasminogen I at the site of a balloon de-endothelializing injury in vivo to the rabbit aorta: Comparison with other hemostatic proteins. J Lab Clin Med 134: 260-266, 1999.

41. Mølgaard L, Ponting CP and Christensen U: Glycosylation at Asn-289 facilitates the ligand-induced conformational changes of human Glu-plasminogen. FEBS Lett 405: 363-368, 1997.

42. Abdul S, Leebeek FW, Rijken DC and Uitte de Willige S Natural heterogeneity of $\alpha 2$-antiplasmin: Functional and clinical consequences. Blood 127: 538-545, 2016.

43. Stefansson S, Lawrence DA and Argraves WS: Plasminogen activator inhibitor-1 and vitronectin promote the cellular clearance of thrombin by low density lipoprotein receptor-related proteins 1 and 2. J Biol Chem 271: 8215-8220, 1996.

44. Ainsworth S, Carter S, Fisher C, Dawson J, Makrides L, Nuttall T and Mason SL: Ligneous membranitis in Scottish Terriers is associated with a single nucleotide polymorphism in the plasminogen (PLG) gene. Anim Genet 46: 707-710, 2015.

45. Silva GB, Bariani C, Mendonça EF and Batista AC: Clinical manifestations due to severe plasminogen deficiency: A case report. J Dent Child(Chic) 73: 179-182, 2006.

46. Celkan T: Plasminogen deficiency. J Thromb Thrombolysis 43 : 132-138, 2017.

47. Sivolella S, De Biagi M, Sartori MT, Berengo M and Bressan E: Destructive membranous periodontal disease (ligneous gingivitis): A literature review. J Periodontol 83: 465-476, 2012.
48. Lotan TL, Tefs K, Schuster V, Miller J, Manaligod J, Filstead A, Yamada SD and Krausz T: Inherited plasminogen deficiency presenting as ligneous vaginitis: A case report with molecular correlation and review of the literature. Hum Pathol 38: $1569-1575,2007$.

49. Gunhan O, Günhan M, Berker E, Gürgan CA and Yildirim H: Destructive membranous periodontal disease (Ligneous periodontitis). J Periodontol 70: 919-925, 1999.

50. Cohen SR: Ligneous conjunctivitis: An ophthalmic disease with potentially fatal tracheobronchial obstruction. Laryngeal and tracheobronchial features. Ann Otol Rhinol Laryngol 99: 509-512, 1990.

51. Foley JH, Kim PY, Mutch NJ and Gils A: Insights into thrombin activatable fibrinolysis inhibitor function and regulation. J Thromb Haemost 11 (Suppl 1): S306-S315, 2013.

52. Kolev K, Longstaff $\mathrm{C}$ and Machovich R: Fibrinolysis at the fluid-solid interface of thrombi. Curr Med Chem Cardiovasc Hematol Agents 3: 341-355, 2005.

53. Bode W and Renatus M: Tissue-type plasminogen activator: Variants and crystal/solution structures demarcate structural determinants of function. Curr Opin Struct Biol 7: 865-872, 1997.

54. Marcos-Contreras OA, Martinez de Lizarrondo S, Bardou I, Orset C,Pruvost M, Anfray A, Frigout Y, Hommet Y, Lebouvier L, Montaner $\mathrm{J}$, et al: Hyperfibrinolysis increases blood-brain barrier permeability by a plasmin- and bradykinin-dependent mechanism. Blood 128: 2423-2434, 2016.

55. Chapman MP, Moore EE, Moore HB, Gonzalez E, Gamboni F, Chandler JG, Mitra S, Ghasabyan A, Chin TL, Sauaia A, et al: Overwhelming tPA release, not PAI-1 degradation, is responsible for hyperfibrinolysis in severely injured trauma patients. J Trauma Acute Care Surg 80: 16-23; discussion 23-15, 2016.

56. Cardenas JC, Matijevic N, Baer LA, Holcomb JB, Cotton BA and Wade CE: Elevated tissue plasminogen activator and reduced plasminogen activator inhibitor promote hyperfibrinolysis in trauma patients. Shock 41: 514-521, 2014.

57. Genét GF, Ostrowski SR, Sørensen AM and Johansson PI: Detection of tPA-induced hyperfibrinolysis in whole blood by RapidTEG, KaolinTEG, and functional fibrinogenTEG in healthy individuals. Clin Appl Thromb Hemost 18: 638-644, 2012.

58. Prabhudesai A, Shetty S, Ghosh K and Kulkarni B: Dysfunctional fibrinolysis and cerebral venous thrombosis. Blood Cells Mol Dis 65: 51-55, 2017.

59. Talens S, Malfliet JJ, Rudež G, Spronk HM, Janssen NA, Meijer P, Kluft C, de Maat MP and Rijken DC: Biological variation in tPA-induced plasma clot lysis time. Thromb Haemost 108: 640-646, 2012.

60. Wang J, Li J and Liu Q: Association between platelet activation and fibrinolysis in acute stroke patients. Neurosci Lett 384: 305-309, 2005

61. Simone TM and Higgins PJ: Low molecular weight antagonists of plasminogen activator inhibitor-1: Therapeutic potential in cardiovascular disease. Mol Med Ther 1: 101, 2012.

62. Higazi AA, Upson RH, Cohen RL, Manuppello J, Bognacki J, Henkin J, McCrae KR, Kounnas MZ, Strickland DK, Preissner KT, et al: Interaction of single-chain urokinase with its receptor induces the appearance and disappearance of binding epitopes within the resultant complex for other cell surface proteins. Blood 88: 542-551, 1996.

63. Finckh U, van Hadeln K, Müller-Thomsen T, Alberici A, Binetti G, Hock C, Nitsch RM, Stoppe G, Reiss J and Gal A: Association of late-onset Alzheimer disease with a genotype of PLAU, the gene encoding urokinase-type plasminogen activator on chromosome 10q22.2. Neurogenetics 4: 213-217, 2003.

64. Goto Y, Hagikura S, Katsuda N and Hamajima N: A C to T polymorphism of urokinase plasminogen activator $(\mathrm{P} 141 \mathrm{~L})$ is associated with Helicobacter pylori infection. Asian Pac J Cancer Prev 12: 803-806, 2011.

65. Kriegbaum MC, Persson M, Haldager L, Alpízar-Alpízar W, Jacobsen B, Gårdsvoll H, Kjær A and Ploug M: Rational targeting of the urokinase receptor (uPAR): Development of antagonists and non-invasive imaging probes. Curr Drug Targets 12: 1711-1728, 2011.

66. Romer J, Nielsen BS and Ploug M: The urokinase receptor as a potential target in cancer therapy. Curr Pharm Des 10: 2359-2376, 2004.

67. Ploug M, Gardsvoll H, Jorgensen TJ, Lønborg Hansen L and Dano K: Structural analysis of the interaction between urokinase-type plasminogen activator and its receptor: A potential target for anti-invasive cancer therapy. Biochem Soc Trans 30: 177-183, 2002. 
68. Manetti M, Allanore Y, Revillod L, Fatini C, Guiducci S, Cuomo G, Bonino C, Riccieri V, Bazzichi L, Liakouli V, et al: A genetic variation located in the promoter region of the UPAR (CD87) gene is associated with the vascular complications of systemic sclerosis. Arthritis Rheum 63: 247-256, 2011.

69. Shih CM, Kuo WH, Lin CW, Chen W, Cheng WE, Chen SC and Lee YL: Association of polymorphisms in the genes of the urokinase plasminogen activation system with susceptibility to and severity of non-small cell lung cancer. Clin Chim Acta 412: 194-198, 2011.

70.Flevaris $\mathrm{P}$ and Vaughan D: The role of plasminogen activator inhibitor type-1 in fibrosis. Semin Thromb Hemost 43: 169-177, 2017.

71.Jankun J, Yang J, Zheng H, Han FQ, Al-Senaidy A and Skrzypczak-Jankun E: Remarkable extension of PAI-1 half-life surprisingly brings no changes to its structure. Int J Mol Med 29: 61-64, 2012

72. Rabieian R, Boshtam M, Zareei M, Kouhpayeh S, Masoudifar A and Mirzaei H: Plasminogen activator inhibitor type-1 as a regulator of fibrosis. J Cell Biochem 119: 17-27, 2018.

73. Piao L, Jung I, Huh JY, Miyata T and Ha H: A novel plasminogen activator inhibitor-1 inhibitor, TM5441, protects against high-fat diet-induced obesity and adipocyte injury in mice. $\mathrm{Br} \mathrm{J}$ Pharmacol 173: 2622-2632, 2016

74. Srikanthan K, Feyh A, Visweshwar H, Shapiro JI and Sodhi K: Systematic review of metabolic syndrome biomarkers: A panel for early detection, management, and risk stratification in the west virginian population. Int J Med Sci 13: 25-38, 2016.

75. Magdoud K, Herbepin VG, Touraine R, Almawi WY and Mahjoub T: Plasminogen activator inhibitor $14 \mathrm{G} / 5 \mathrm{G}$ and $-844 \mathrm{G} / \mathrm{A}$ variants in idiopathic recurrent pregnancy loss. Am J Reprod Immunol 70: 246-252, 2013.

76. Honig A, Engel JB, Segerer SE, Kranke P, Häusler S and Wurfel W: Pregnancy-triggered antiphospholipid syndrome in a patient with multiple late miscarriages. Hum Reprod 25 2753-2754, 2010.

77.Jankun J and Skrzypczak-Jankun E: Bleeding diathesis is associated with an A15T heterozygous mutation in exon 2 of the plasminogen activator inhibitor type 1. Exp Ther Med 1: 575-577, 2010.

78. Mehta R and Shapiro AD: Plasminogen activator inhibitor type 1 deficiency. Haemophilia 14: 1255-1260, 2008.

79. Schleef RR, Higgins DL, Pillemer E and Levitt LJ: Bleeding diathesis due to decreased functional activity of type 1 plasminogen activator inhibitor. J Clin Invest 83: 1747-1752, 1989.

80. Heiman M, Gupta S and Shapiro AD: The obstetric, gynaecological and fertility implications of homozygous PAI-1 deficiency: Single-centre experience. Haemophilia 20: 407-412, 2014.

81.Lin S, Huiya Z, Bo L, Wei W and Yongmei G: The plasminogen activator inhibitor-1 (PAI-1) gene $-844 \mathrm{~A} / \mathrm{G}$ and $-6754 \mathrm{G} / 5 \mathrm{G}$ promoter polymorphism significantly influences plasma PAI-1 levels in women with polycystic ovary syndrome. Endocrine 36 : 503-509, 2009.

82. Fay WP, Parker AC, Condrey LR and Shapiro AD: Human plasminogen activator inhibitor-1 (PAI-1) deficiency: Characterization of a large kindred with a null mutation in the PAI-1 gene. Blood 90: 204-208, 1997.

83. Jankun J and Skrzypczak-Jankun E: Val17Ile single nucleotide polymorphisms similarly as Ala15Thr could be related to the lower secretory dynamics of PAI-1 secretion: Theoretical evidence. Curr Mol Med 11: 512-516, 2011.

84. Miao C, Liang C, Zhu J, Xu A, Zhao K, Hua Y, Zhang J, Chen W, Suo C, Zhang C, et al: Prognostic role of matrix metalloproteinases in bladder carcinoma: A systematic review and meta-analysis. Oncotarget 8: 32309-32321, 2017.

85. Turunen SP, Tatti-Bugaeva O and Lehti K: Membrane-type matrix metalloproteases as diverse effectors of cancer progression. Biochim Biophys Acta 1864: 1974-1988, 2017.

86. Van Lint $\mathrm{P}$ and Libert $\mathrm{C}$ : Chemokine and cytokine processing by matrix metalloproteinases and its effect on leukocyte migration and inflammation. J Leuk Biol 82: 1375-1381, 2007.

87. Verma RP and Hansch C: Matrix metalloproteinases (MMPs): Chemical-biological functions and (Q)SARs. Bioorg Med Chem 15: 2223-2268, 2007.

88. Swarnakar S, Paul S, Singh LP and Reiter RJ: Matrix metalloproteinases in health and disease: Regulation by melatonin J Pineal Res 50: 8-20, 2011.

89.Zitka O, Kukacka J, Krizkova S, Huska D, Adam V, Masarik M, Prusa R and Kizek R: Matrix metalloproteinases. Curr Med Chem 17: 3751-3768, 2010
90. Fisher KE, Fei Q, Laird ER, Stock JL, Allen MR, Sahagan BG and Strick CA: Engineering autoactivating forms of matrix metalloproteinase-9 and expression of the active enzyme in cultured cells and transgenic mouse brain. Biochemistry 41 : 8289-8297, 2002

91. Marchenko GN, Ratnikov BI, Rozanov DV, Godzik A, Deryugina EI and Strongin AY: Characterization of matrix metalloproteinase-26, a novel metalloproteinase widely expressed in cancer cells of epithelial origin. Biochem J 356: 705-718, 2001

92. Merchant N, Nagaraju GP, Rajitha B, Lammata S, Jella KK, Buchwald ZS, Lakka SS and Ali AN: Matrix metalloproteinases: Their functional role in lung cancer. Carcinogenesis 38: 766-780, 2017.

93. Morgunova E, Tuuttila A, Bergmann U, Isupov M, Lindqvist $\mathrm{Y}$, Schneider G and Tryggvason K: Structure of human pro-matrix metalloproteinase-2: Activation mechanism revealed. Science 284: 1667-1670, 1999.

94. Su SC, Hsieh MJ, Yang WE, Chung WH, Reiter RJ and Yang SF Cancer metastasis: Mechanisms of inhibition by melatonin J Pineal Research 62, 2017.

95. Webb AH, Gao BT, Goldsmith ZK, Irvine AS, Saleh N, Lee RP, Lendermon JB, Bheemreddy R, Zhang Q, Brennan RC, et al: Inhibition of MMP-2 and MMP-9 decreases cellular migration, and angiogenesis in in vitro models of retinoblastoma. BMC Cancer 17: 434, 2017.

96. Eiro N, Fernandez-Gomez J, Sacristan R, Sacristán R, Fernandez-Garcia B, Lobo B, Gonzalez-Suarez J, Quintas A, Escaf S and Vizoso FJ: Stromal factors involved in human prostate cancer development, progression and castration resistance. J Cancer Res Clin Oncol 143: 351-359, 2017.

97. Gialeli C, Theocharis AD and Karamanos NK: Roles of matrix metalloproteinases in cancer progression and their pharmacological targeting. FEBS J 278: 16-27, 2011.

98. Grieu F, Li WQ and Iacopetta B: Genetic polymorphisms in the MMP-2 and MMP-9 genes and breast cancer phenotype. Breast Cancer Res Treat 88: 197-204, 2004.

99. Singh R, Srivastava P, Srivastava A and Mittal RD: Matrix metalloproteinase (MMP-9 and MMP-2) gene polymorphisms influence allograft survival in renal transplant recipients. Nephrol Dial Transplant 25: 3393-3401, 2010.

100. Ghaffarpour S, Ghazanfari T, Kabudanian Ardestani S, Pourfarzam S, Fallahi F, Shams J, Mirsharif ES, Mohseni Majd AM and Faghihzadeh S: Correlation between MMP-9 and MMP-9/ TIMPs complex with pulmonary function in sulfur mustard exposed civilians: Sardasht-Iran cohort study. Arch Iran Med 20: 74-82, 2017.

101. Ricci S, Bruzzese D and DI Carlo A: Evaluation of MMP-2, MMP-9, TIMP-1, TIMP-2, NGAL and MMP-9/NGAL complex in urine and sera from patients with bladder cancer. Oncol Lett 10: 2527-2532, 2015 .

102. Hinterseher I, Krex D, Kuhlisch E, Schmidt KG, Pilarsky C, Schneiders W, Saeger HD and Bergert H: Tissue inhibitor of metalloproteinase-1 (TIMP-1) polymorphisms in a Caucasian population with abdominal aortic aneurysm. World J Surg 31: 2248-2254, 2007

103. Xu P, Guo W, Jin T, Wang J, Fan D, Hao Z, Jing S, Han C, Du J, Jiang D, et al: TIMP-2 SNPs rs7342880 and rs4789936 are linked to risk of knee osteoarthritis in the Chinese Han Population. Oncotarget 8: 1166-1176, 2017.

104. Birbrair A, Zhang T, Wang ZM, Messi ML, Olson JD, Mintz A and Delbono O: Type-2 pericytes participate in normal and tumoral angiogenesis. Am J Physiol Cell Physiol 307: C25-C38, 2014.

105. Lah TT, Durán Alonso MB and Van Noorden CJ: Antiprotease therapy in cancer: Hot or not? Exp Opin Biol Ther 6: 257-279, 2006.

106. Wong MS, Sidik SM, Mahmud R and Stanslas J: Molecular targets in the discovery and development of novel antimetastatic agents: Current progress and future prospects. Clin Exp Pharmacol Physiol 40: 307-319, 2013.

107. Jankun J, Maher VM and McCormick JJ: Malignant transformation of human fibroblasts correlates with increased activity of receptor-bound plasminogen activator. Cancer Res 51: $1221-1226,1991$

108. Jankun J, Selman SH, Aniola J and Skrzypczak-Jankun E: Nutraceutical inhibitors of urokinase: Potential applications in prostate cancer prevention and treatment. Oncol Rep 16 : 341-346, 2006.

109. Kamat AM and Lamm DL: Chemoprevention of bladder cancer. Urol Clin North Am 29: 157-168, 2002. 
110. Swiercz R, Skrzypczak-Jankun E, Merrell MM, Selman SH and Jankun J: Angiostatic activity of synthetic inhibitors of urokinase type plasminogen activator. Oncol Rep 6: 523-526, 1999.

111. Jankun J, Selman SH, Swiercz R and Skrzypczak-Jankun E: Why drinking green tea could prevent cancer. Nature 387: 561, 1997

112. Kemberling JK, Hampton JA, Keck RW, Gomez MA and Selman SH: Inhibition of bladder tumor growth by the green tea derivative epigallocatechin-3-gallate. J Urol 170: 773-776, 2003.

113. Jankun J, Keck RW and Selman SH: Epigallocatechin-3-gallate prevents tumor cell implantation/growth in an experimental rat bladder tumor model. Int J Oncol 44: 147-152, 2014.

114. Wendt MD, Geyer A, McClellan WJ, Rockway TW, Weitzberg M, Zhao X, Mantei R, Stewart K, Nienaber V, Klinghofer V and Giranda VL: Interaction with the S1 beta-pocket of urokinase: 8-heterocycle substituted and 6,8-disubstituted 2-naphthamidine urokinase inhibitors. Bioorg Med Chem Lett 14: 3063-3068, 2004.

115. Bruncko M, McClellan WJ, Wendt MD, Sauer DR, Geyer A, Dalton CR, Kaminski MA, Weitzberg M, Gong J, Dellaria JF, et al: Naphthamidine urokinase plasminogen activator inhibitors with improved pharmacokinetic properties. Bioorg Med Chem Lett 15: 93-98, 2005.

116. Katz BA, Sprengeler PA, Luong C, Verner E, Elrod K, Kirtley M, Janc J, Spencer JR, Breitenbucher JG, Hui H, et al: Engineering inhibitors highly selective for the S1 sites of Ser190 trypsin-like serine protease drug targets. Chem Biol 8: 1107-1121, 2001.

117. Schmitt M, Harbeck N, Brünner N, Jänicke F, Meisner C Mühlenweg B, Jansen H, Dorn J, Nitz U, Kantelhardt EJ and Thomssen C: Cancer therapy trials employing level-of-evidence-1 disease forecast cancer biomarkers uPA and its inhibitor PAI-1. Exp Rev Mol Diagn 11: 617-634, 2011.

118.Zengel P, Ramp D, Mack B, Zahler S, Berghaus A, Muehlenweg B, Gires O and Schmitz S: Multimodal therapy for synergic inhibition of tumour cell invasion and tumour-induced angiogenesis. BMC Cancer 10: 92, 2010.

119. Setyono-Han B, Stürzebecher J, Schmalix WA, Muehlenweg B, Sieuwerts AM, Timmermans M, Magdolen V, Schmitt M, Klijn JG and Foekens JA: Suppression of rat breast cancer metastasis and reduction of primary tumour growth by the small synthetic urokinase inhibitor WX-UK1. Thromb Haemost 93 779-786, 2005.

120. Ertongur S, Lang S, Mack B, Wosikowski K, Muehlenweg B and Gires O: Inhibition of the invasion capacity of carcinoma cells by WX-UK1, a novel synthetic inhibitor of the urokinase-type plasminogen activator system. Int J Cancer 110: 815-824, 2004.

121. Ossowski L: Invasion of connective tissue by human carcinoma cell lines: Requirement for urokinase, urokinase receptor, and interstitial collagenase. Cancer Res 52: 6754-6760, 1992.

122. Ossowski L: In vivo invasion of modified chorioallantoic membrane by tumor cells: The role of cell surface-bound urokinase. J Cell Biol 107: 2437-2445, 1988.

123. Jankun J, Keck RW, Skrzypczak-Jankun E and Swiercz R: Inhibitors of urokinase reduce size of prostate cancer xenografts in severe combined immunodeficient mice. Cancer Res 57: 559-563, 1997.

124.Berkenpas MB, Lawrence DA and Ginsburg D: Molecular evolution of plasminogen activator inhibitor-1 functional stability. EMBO J 14: 2969-2977, 1995.

125. Chorostowska-Wynimko J, Swiercz R, Skrzypczak-Jankun E, Wojtowicz A, Selman SH and Jankun J: A novel form of the plasminogen activator inhibitor created by cysteine mutations extends its half-life: Relevance to cancer and angiogenesis. Mol Cancer Ther 2: 19-28, 2003.

126. Tucker HM, Mottonen J, Goldsmith EJ and Gerard RD: Engineering of plasminogen activator inhibitor-1 to reduce the rate of latency transition. Nat Struct Biol 2: 442-445, 1995.

127. Binder BR and Mihaly J: The plasminogen activator inhibitor 'paradox' in cancer. Immunol Lett 118: 116-124, 2008.

128. Beaulieu LM, Whitley BR, Wiesner TF, Rehault SM, Palmieri D Elkahloun AG and Church FC: Breast cancer and metabolic syndrome linked through the plasminogen activator inhibitor-1 cycle. Bioessays 29: 1029-1038, 2007.

129.Duffy MJ: Urokinase plasminogen activator and its inhibitor, PAI-1, as prognostic markers in breast cancer: From pilot to level 1 evidence studies. Clin Chem 48: 1194-1197, 2002.

130. Chorostowska-Wynimko J, Swiercz R, Skrzypczak-Jankun E, Selman SH and Jankun J: Plasminogen activator inhibitor type-1 mutants regulate angiogenesis of human umbilical and lung vascular endothelial cells. Oncol Rep 12: 1155-1162, 2004
131. Masset A, Maillard C, Sounni NE, Jacobs N, Bruyére F, Delvenne P, Tacke M, Reinheckel T, Foidart JM, Coussens LM and Noël A: Unimpeded skin carcinogenesis in K14-HPV16 transgenic mice deficient for plasminogen activator inhibitor. Int J Cancer 128: 283-293, 2011.

132. Mazar AP, Henkin J and Goldfarb RH: The urokinase plasminogen activator system in cancer: Implications for tumor angiogenesis and metastasis. Angiogenesis 3: 15-32, 1999.

133. Wyganowska-Świątkowska $M$ and Jankun J: Plasminogen activation system in oral cancer: Relevance in prognosis and therapy (Review). Int J Oncol 47: 16-24, 2015.

134. Chen SC, Henry DO, Hicks DG, Reczek PR and Wong MK: Intravesical administration of plasminogen activator inhibitor type-1 inhibits in vivo bladder tumor invasion and progression. J Urol 181: 336-342, 2009

135. Yamakawa S, Asai T, Uchida T, Matsukawa M, Akizawa T and Oku N: (-)-Epigallocatechin gallate inhibits membrane-type 1 matrix metalloproteinase, MT1-MMP, and tumor angiogenesis. Cancer Lett 210: 47-55, 2004.

136. Stefansson S, Petitclerc E, Wong MK, McMahon GA, Brooks PC and Lawrence DA: Inhibition of angiogenesis in vivo by plasminogen activator inhibitor-1. J Biol Chem 276: 8135-8141, 2001.

137. Su SC, Lin CW, Yang WE, Fan WL and Yang SF: The urokinasetype plasminogen activator (uPA) system as a biomarker and therapeutic target in human malignancies. Exp Opin Ther Targets 20: 551-566, 2016.

138. Ulisse S, Baldini E, Sorrenti S and D'Armiento M: The urokinase plasminogen activator system: A target for anti-cancer therapy. Curr Cancer Drug Targets 9: 32-71, 2009.

139. Iwamoto J, Mizokami Y, Takahashi K, Nakajima K, Ohtsubo T, Miura S, Narasaka T, Takeyama H, Omata T, Shimokobe K, et al: Expressions of urokinase-type plasminogen activator, its receptor and plasminogen activator inhibitor-1 in gastric cancer cells and effects of Helicobacter pylori. Scand J Gastroenterol 40: 783-793, 2005

140.Haj-Yehia A,Nassar T, Sachais BS, Kuo A, Bdeir K, Al-Mehdi AB, Mazar A, Cines DB and Higazi AA: Urokinase-derived peptides regulate vascular smooth muscle contraction in vitro and in vivo. FASEB J 14: 1411-1422, 2000.

141. Guo Y, Higazi AA, Arakelian A, Sachais BS, Cines D, Goldfarb RH, Jones TR, Kwaan H, Mazar AP and Rabbani SA: A peptide derived from the nonreceptor binding region of urokinase plasminogen activator (uPA) inhibits tumor progression and angiogenesis and induces tumor cell death in vivo. FASEB J 14: 1400-1410, 2000.

142. Berkenblit A, Matulonis UA, Kroener JF, Dezube BJ, Lam GN, Cuasay LC, Brünner N, Jones TR, Silverman MH and Gold MA: A6, a urokinase plasminogen activator (uPA)-derived peptide in patients with advanced gynecologic cancer: A phase I trial. Gynecol Oncol 99: 50-57, 2005.

143. Mani T, Wang F, Knabe WE, Sinn AL, Khanna M, Jo I, Sandusky GE, Sledge GW Jr, Jones DR, Khanna R, et al: Small-molecule inhibition of the uPAR.uPA interaction: Synthesis, biochemical, cellular, in vivo pharmacokinetics and efficacy studies in breast cancer metastasis. Bioorg Med Chem 21: 2145-2155, 2013.

144. Wang F, Eric Knabe W, Li L, Jo I, Mani T, Roehm H, Oh K, Li J, Khanna M and Meroueh SO: Design, synthesis, biochemical studies, cellular characterization, and structure-based computational studies of small molecules targeting the urokinase receptor. Bioorg Med Chem 20: 4760-4773, 2012.

145. Jian Q, Yang Z, Shu J, Liu X, Zhang J and Li Z: Lectin BS-I inhibits cell migration and invasion via AKT/GSK-3 $\beta / \beta$-catenin pathway in hepatocellular carcinoma. J Cell Mol Med 22: $315-329,2018$

146. Li H and Chen C: Quercetin has antimetastatic effects on gastric cancer cells via the interruption of uPA/uPAR function by modulating NF- $\kappa b$, PKC- $\delta$, ERK1/2, and AMPK $\alpha$. Integr Cancer Ther 17: 511-523, 2018.

147. Cathcart J, Pulkoski-Gross A and Cao J: Targeting matrix metalloproteinases in cancer: Bringing new life to old ideas. Genes Dis 2: 26-34, 2015.

148. Rothenberg ML, Nelson AR and Hande KR: New drugs on the horizon: Matrix metalloproteinase inhibitors. Oncologist 3: 271-274, 1998

149. Rothenberg ML, Nelson AR and Hande KR: New drugs on the horizon: Matrix metalloproteinase inhibitors. Stem cells 17: 237-240, 1999 
150. Coussens LM, Fingleton B and Matrisian LM: Matrix metalloproteinase inhibitors and cancer: Trials and tribulations. Science 295: 2387-2392, 2002.

151. Martens E, Leyssen A, Van Aelst I, Fiten P, Piccard H, Hu J, Descamps FJ, Van den Steen PE, Proost P, Van Damme J, et al: A monoclonal antibody inhibits gelatinase B/MMP-9 by selective binding to part of the catalytic domain and not to the fibronectin or zinc binding domains. Biochim Biophys Acta 1770: 178-186, 2007.

152.Kaimal R, Aljumaily R, Tressel SL, Pradhan RV, Covic L, Kuliopulos A, Zarwan C, Kim YB, Sharifi S and Agarwal A: Selective blockade of matrix metalloprotease-14 with a monoclonal antibody abrogates invasion, angiogenesis, and tumor growth in ovarian cancer. Cancer Res 73: 2457-2467, 2013.
153. Shay G, Lynch CC and Fingleton B: Moving targets: Emerging roles for MMPs in cancer progression and metastasis. Matrix Biol 44-46: 200-206, 2015.

(i) (9) This work is licensed under a Creative Commons Attribution-NonCommercial-NoDerivatives 4.0 International (CC BY-NC-ND 4.0) License. 